University of South Carolina

Scholar Commons

2006

\title{
Woman-Centered Post-Abortion Care in Public Hospitals in Tucumán, Argentina: Assessing Quality of Care and Its Link to Human Rights
}

Rodolfo Gómez Ponce de León

Deborah Lynn Billings

University of South Carolina - Columbia, billindl@mailbox.sc.edu

Karina Barrionuevo

Follow this and additional works at: https://scholarcommons.sc.edu/

sph_health_promotion_education_behavior_facpub

Part of the Public Health Commons

Publication Info

Published in Health and Human Rights, ed. Sofia Gruskin, Volume 9, Issue 1, 2006, pages 174-201.

Gómez Ponce de León, R., Billings, D. L., \& Barrionuevo, K. (2006). Woman-centered post-abortion care in public hospitals in Tucumán, Argentina: Accessing quality of care and its link to human rights. Health and Human Rights, 9(1), 174-201.

(c) Health and Human Rights, 2006, Harvard School of Public Health

This Article is brought to you by the Health Promotion, Education, and Behavior at Scholar Commons. It has been accepted for inclusion in Faculty Publications by an authorized administrator of Scholar Commons. For more information, please contact digres@mailbox.sc.edu. 


\begin{abstract}
Unsafe abortion is a major public health and human rights problem in Argentina. Implementation of a woman-centered post-abortion care (PAC) model is one strategy to improve the situation. The quality of PAC services was measured in three public hospitals in Tucumán, a province with high levels of poverty and maternal mortality due to unsafe abortion. Overall, the quality of PAC services was found to be poor. Women do not receive services in a manner that respects their human rights, in particular their rights to health and health care, information, and to the benefits of scientific progress. Findings from the evaluation are being used to develop collaborative NGO/hospital/policy-maker efforts to improve PAC services through better training of health care providers.
\end{abstract}

L'avortement à risque est un grave problème touchant à la santé et aux droits de l'homme en Argentine. La mise en place d'un modèle de soins après avortement (PAC) axé sur une approche est une stratégie visant à remédier à cette situation. La qualité des soins après avortement (PAC) a été mesurée dans trois hôpitaux publics de Tucumán, une province présentant des taux de pauvreté et de morbidité maternelle importants, dus aux avortements à risque. Dans l'ensemble, la qualité des soins après avortement (PAC) s'est avérée être médiocre. Les femmes ne sont pas traitées dans le respect des droits de la personne; en particulier, lorsque ceux ci concernent les droits à la santé et aux soins de santé, le droit à l'information et le droit à bénéficier des progrès scientifiques. Les conclusions obtenues à l'issue de cette évaluation sont appliquées au développement des efforts collaboratifs entre ONG, hôpitaux et décideurs afin d'améliorer les soins après avortement, en particulier la formation des dispensateurs de soins de santé.

Los abortos inseguros son un problema importante de salud pública y de derechos humanos en la Argentina. Una estrategia diseñada para mejorar la situación es el uso del modelo de atención posterior al aborto (APA) centrado en la mujer. En tres hospitales públicos de Tucumán, una provincia con niveles altos de pobreza y de mortalidad materna debido al aborto inseguro, se midió la calidad de los servicios de APA. En general, se encontró que la calidad de los servicios de APA es mala. Las mujeres no reciben servicios de forma respetuosa para con sus derechos humanos, en especial sus derechos a la salud y al cuidado de la salud, a la información y a los beneficios del progreso científico. Los descubrimientos de la evaluación se están usando para crear esfuerzos cooperativos entre organizaciones no gubernamentales, hospitales y dirigentes para mejorar los servicios de APA mediante la mejor capacitación de los proveedores de atención médica. 


\title{
WomAn-Centered Post-Abortion CARe in Public Hospitals in TuCumán, Argentina: Assessing Quality of Care and Its Link to Human Rights
}

\author{
Rodolfo Gómez Ponce de León, Deborah L. Billings, \\ and Karina Barrionuevo
}

All Governments and ... non-governmental organizations are urged to strengthen their commitment to women's health, to deal with the health impact of unsafe abortion as a major public health concern, and to reduce the recourse to abortion through expanded and improved family planning services. Prevention of unwanted pregnancies must always be given the highest priority and all attempts should be made to eliminate the need for abortion. ... In circumstances in which abortion is not against the law, such abortion should be safe. In all cases women should have access to quality services for the management of complications arising from abortion. Post-abortion counseling, education, and family planning services should be offered promptly which will also help to avoid repeat abortions.

International Conference on

Population and Development (ICPD)

Programme of Action, from Paragraph 8.25

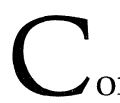

omplications from unsafe abortion, defined as a procedure for terminating an unwanted pregnancy, either by persons lacking the necessary skills, or taking place in an environment lacking the minimal medical standards, or both, remain a significant cause of maternal morbidity and mortality, despite the fact that most complications are preventable. ${ }^{2}$ Of the estimated 19 million unsafe abortions that

Rodolfo Gómez Ponce de León, PhD, is Senior Health System Advisor at Ipas, Chapel Hill, North Carolina; Deborah L Billings, PhD, is a Senior Research Associate at Ipas, based in Mexico City; Karina Barrionuevo is Coordinator of Psychology Services, Perinatal Care, Avellaneda Hospital, San Miguel de Tucumán, Argentina. Please address correspondence to the authors at gomezr@ipas.org.

Copyright (c) 2006 by the President and Fellows of Harvard College and Ipas. 
take place each year throughout the world, almost all $(97 \%)$ are among women in developing countries. ${ }^{3}$ An estimated 3.7 million unsafe abortions are carried out each year in the Latin American and Caribbean regions, with 2.9 million taking place in South America, resulting in approximately $19 \%$ of all maternal deaths attributable to complications of unsafe abortion in this part of the world. ${ }^{4}$ Abortion laws throughout Latin America restrict women's access to safe services.

Maternal mortality due to unsafe abortion must be evaluated along three axes: public health, human rights, and social justice. Such mortality affects thousands of women each year and is preventable with basic, evidence-based interventions. Human rights standards accepted throughout the world, including Argentina, make it clear that unsafe abortion violates rights ranging from the right to health and life as well as to the benefits of scientific progress. Lastly, the majority of women who die from unsafe abortion are those who are economically, politically, and socially marginalized and without access to safe, albeit illegal abortions, or post-abortion care. Their deaths are a clear expression of social inequity and injustice. ${ }^{5}$

The ability to reach a satisfactory level of reproductive health, as well as to practice sexual and reproductive rights free from coercion, discrimination, and violence is inextricably linked to people's living conditions; to an environment of gender, racial, and class-based equity; and to the implementation of effective public policies aimed at reducing the gaps in access to reproductive-health information and services. ${ }^{6}$

Argentina, like 178 other governments, is signatory to the 1994 International Conference on Population and Development (ICPD) Programme of Action (PoA), obligating the state to create the conditions whereby Paragraph 8.25 can be implemented. Explicit in this important section of the PoA is the need for post-abortion care (PAC), that can meet women's multiple needs when experiencing complications from an unsafe abortion. ${ }^{7}$ Recent studies conducted in Argentina demonstrate severe deficiencies in the quality of PAC services being offered in public sector 
health facilities, which translate into a range of human rights violations for women seeking care. ${ }^{8}, 9$ At the same time, Argentina currently is undergoing important public policy changes related to reproductive health and PAC. In general, activists are making reproductive health more visible in public debates.

The five basic elements of PAC are: 1) Community and service-provider partnerships; 2) Prompt treatment of complications from unsafe abortion using safe and effective clinical methods (including vacuum aspiration [VA] and medication methods); 3) Contraceptive counseling and methods to help women achieve their reproductive intentions and avoid repeat unwanted pregnancies and (unsafe) abortions; 4) General counseling to identify and respond to women's emotional and physical health needs and other concerns; and 5) Other reproductive-health services, offered on-site or through referral, as needed by women experiencing abortion complications. ${ }^{10}$

PAC services that meet high standards of quality and accessibility are essential to advancing women's health and rights, including their right to health and life. By doing so, it is expected that maternal mortality and morbidity due to unsafe abortion will decrease, women's health will improve, and individual women's dignity will be respected as they access a range of services necessary to their wellbeing. Implementing a woman-centered PAC model of care that is grounded in human rights is one important approach to ensuring that women can exercise their rights, despite restrictive legal contexts that create conditions of powerlessness and vulnerability for women seeking care in health institutions. 11,12

In this article, we present findings from research on the quality of PAC services in three public hospitals in Tucumán, Argentina. The "Quality PAC Evaluation Model" (EvalAPA) tool was developed by Ipas to assess the extent to which standards defined by the woman-centered PAC model of care are being met and to set benchmarks for meeting them. Ipas is an international organization that has worked for three decades to increase women's ability to exercise their sexual and reproductive rights and to reduce deaths and injuries of women from unsafe abortion. Ipas' 
global and country programs include this EvalAPA training; for more information, please see www.ipas.org.

EvalAPA was implemented in the three hospitals as one way of measuring the quality of care women received. Researchers used results from EvalAPA, as well as focus groups and in-depth interviews with health care providers and women treated for abortion complications, to engage health care providers and administrators in discussions about the lessons learned and necessary remedial actions. We present the encouraging steps taken to date in these hospitals to move toward services that are more comprehensive and that provide the basic conditions necessary for women to exercise their human rights when seeking care for abortion complications.

\section{Framework of Health As a Human Right for PAC Services}

The right of every human being to enjoy the highest attainable standard of physical and mental health is enshrined in most basic human rights documents that guide work in this area. ${ }^{13}$ This broad definition of the right to health is fundamental to guaranteeing other relevant rights, including nondiscrimination in the provision of health services; universal access to adequate, quality, comprehensive health care; access to the benefits of scientific advancements; the right to liberty and security of person; and the right to be free from degrading treatment. Governments have an obligation to ensure that conditions exist so that these interconnected rights can be exercised.

The right to health is understood to be violated when the ability to decide freely and in an informed manner about the timing and spacing of pregnancy is impeded, including when access to safe and legal abortion services or post-abortion contraceptive services are not available and accessible; when women are denied PAC services because they are not available or because health care providers take a position against abortion; and when women receive substandard or degrading treatment. ${ }^{14}$

ICPD paragraph 8.25 and ICPD+5 paragraph 63 emphasize the need for both governments and civil society to address unsafe abortion as a major public health problem in 
need of attention and investment to ensure the provision of medical care for complications. Quality post-abortion contraceptive services have been shown to prevent repeat unwanted pregnancies by meeting women's needs for methods that help them control their fertility. ${ }^{15}$ It should be noted that PAC services focus attention on care for women who are in life- or health-threatening situations due to the complications of unsafe abortion, rather than preventing the complications from the start. 16 PAC does not fully address the right to health and access to care, but in contexts throughout the world, including Argentina, PAC is a meaningful starting point and absolutely essential to the lives of women who otherwise might suffer long-term detrimental health effects or death. PAC has become a particularly useful way to address the issue of unsafe abortion in countries such as Argentina where abortion is highly stigmatized and legally restricted. ${ }^{17}$ Governments that signed the ICPD PoA committed themselves to offer universal access to high-quality PAC services for all women. The mission of governments is to fulfill this international commitment through the strategy of "training and equipping" health systems.

\section{Abortion in Argentina}

Abortion is exempt from punishment in the federal penal code only when the pregnant woman's life or health is in danger, or when the pregnancy is the result of the rape of a woman who is "an idiot or demented" and her guardian or legal representative allows the abortion. ${ }^{18}$ In both cases, the abortion must be performed by a physician with the woman's consent.

An estimated 800,000 abortions, nonetheless, are carried out every year in Argentina, with only 10\% performed under safe conditions. ${ }^{19,20}$

Approximately one in every 250 abortions ends in a woman's death; this translates into four women dying each day from unsafe abortion in Argentina. ${ }^{21,22}$ Among women who survive, many suffer complications that require medical attention. More women are seeking care, reflected in the $57 \%$ increase in demand for post-abortion care in public hospitals in Argentina from 1995 to $2000 .{ }^{23}$ 


\section{Argentine Context for PAC Services}

Argentina possesses positive indicators of health, relative to other Latin American countries. ${ }^{24}$ Infant mortality for 2000-2005 was 14 per 1,000 live births; life expectancy currently stands at 78 for women and 71 for men, and $99 \%$ of all births are attended by trained personnel.25,26 This appearance of affluence, however, masks important regional variations, in which Tucumán ranks as Argentina's poorest province. Throughout the country, approximately $22 \%$ of the population or nearly 8 million people do not have their basic needs met and receive no public benefits whatsoever. ${ }^{27}$ The social security network provides coverage only to $25 \%$ of poor families in the country. 28 At the same time, increasing unemployment has caused many people to lose their health care coverage. An analysis by age group shows that people between the ages of 20 and 29 have the lowest levels of health care coverage. ${ }^{29}$ Thus, during a period in which significant numbers of women become pregnant, they have no health insurance to help meet their basic needs. 30

Throughout Argentina, a strong women's movement mobilized during the 1980s and 1990s for structural changes that have resulted in greater representation in political parties and government, a constitutional reform that mandates equal opportunities for men and women, and advances in education and participation in the paid workforce. However, women's status remains low, as evidenced by lower pay for similar work, less job security, and high maternal mortality, when compared to other countries of similar socio-economic standing, at 82 deaths (related to pregnancy, delivery, and other complications) per 100,000 live births. An estimated one-third of these deaths was caused by complications from unsafe abortion, a direct result of women's limited access to contraceptive methods. 31,32 Access is especially difficult for poor women, those living in more conservative provinces, and for young, particularly unmarried, women. 33

Between 1980 and 2000, maternal mortality, including the proportion of deaths due to unsafe abortion, did not change significantly. ${ }^{34}$ Maternal death from unsafe abortion was the number one cause of maternal mortality in Argentina at the beginning of the 1980s and remains so today (see Figure 1)..35 


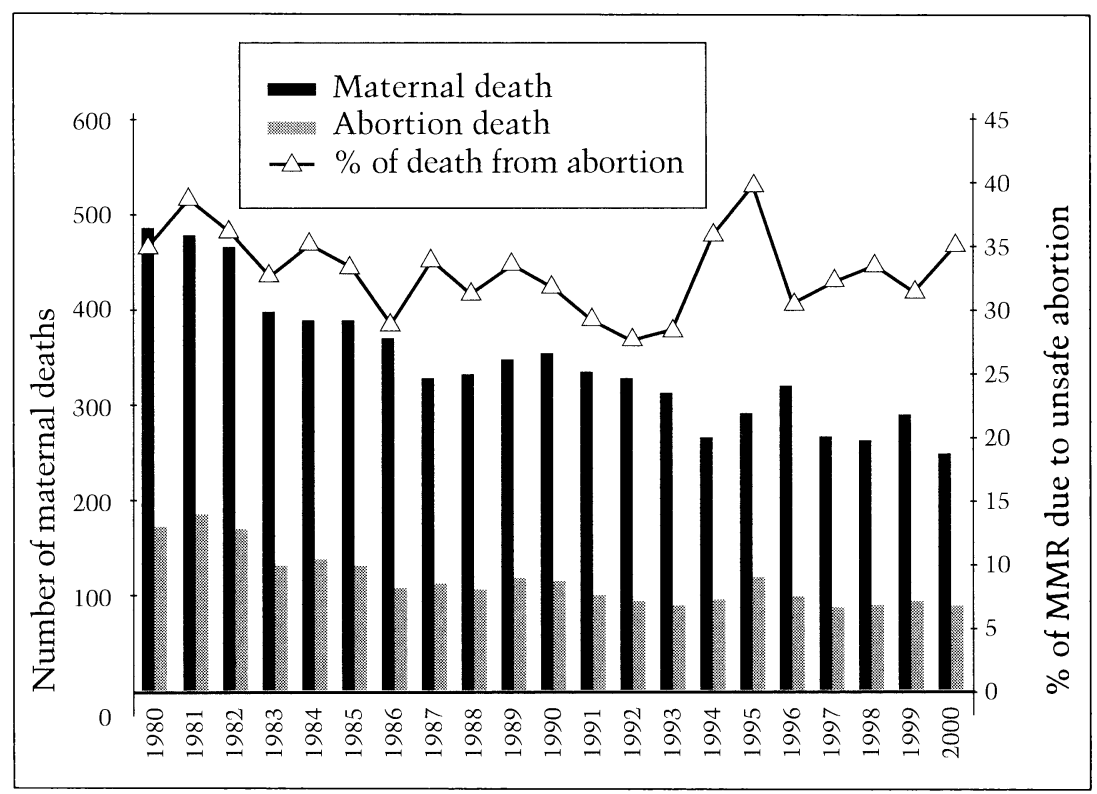

Figure 1. Maternal Mortality Ratio (MMR) and Unsafe Abortion, Argentina, 1980-2000. Source: D. Rocco, "Mortalidad Materna Por Aborto en la Argentina de 1980 al 2000," Obstetricia y Ginecologia Latino Americana 60/4 (2002): pp. 184-9.

\section{Pro-Natalist Policies Versus New Laws to Improve Reproductive Health in Argentina}

Historically, Argentina has fostered "pro-natalist" public policies, and efforts to increase access to contraceptives have been thwarted. ${ }^{36}$ A 1997 bill to establish a National Program for Sexual Health and Responsible Procreation (Programa Nacional de Salud Sexual y Procreación Responsable) was defeated in Congress; at the same time, in 1998, President Menem approved a decree designating March 25th as the Day of the Unborn Child (Día del Niño por Nacer). Activists continued to push for progressive legislation and, despite strong opposition by the Roman Catholic Church, the National Law for Sexual Health and Responsible Procreation was finally passed by the Federal Congress in October 2002.37 This law created the National Program, which applies to all public sector health services, although it needs to be implemented through local regulations in each of Argentina's 24 provinces. Under the Argentine system of government, each province works somewhat independently from the federal system, fol- 
lowing its own local constitution. With this system, 17 of the country's 24 provinces have regulated the national law. Tucumán is one of the provinces where the National Program was not approved by provincial legislators and, thus, is not being fully implemented.

The law aims to reduce infant and maternal mortality, promote sexual health among adolescents, reduce sexually transmitted diseases, prevent unwanted pregnancies, and create conditions that allow women to make reproductive health-related decisions "free from discrimination, coercion, or violence." Among other provisions, the law includes funding to distribute contraceptive pills, condoms, and intra-uterine devices (IUDs) free of charge to women through public sector health services.

\section{Tucumán, Argentina}

Founded by Christian missionaries in the 16th century, Tucumán is Argentina's poorest province. Seventy percent of Tucumán's 1.3 million inhabitants live below the poverty line (US $\$ 195$ or less a month for a family of four), compared with $57 \%$ nationally. A full $43 \%$ live in severe poverty (US\$85 or less a month for a family of four). 38 Tucumán is also one of Argentina's most religious provinces, in which the Roman Catholic Church wields a great deal of power. It is one of the few provinces that has not signed or implemented the National Law for Sexual Health and Responsible Procreation, in large part because of the ongoing activism and opposition of the Archdiocese, which views the use of contraceptives as "morally unacceptable." 39 Despite this extremely conservative social context, women in Tucumán have abortions and most are unsafe; many women suffer dire consequences, including at least 30 deaths per year. ${ }^{40}$

\section{PAC in Argentina}

When PAC services are not delivered with attention to rights, ethics, and social justice, avenues for abuse and violations open, especially in settings where abortion is legally and morally condemned. This is the case in many hospitals in Argentina. ${ }^{41}$ Studies conducted from women's experiences and perspectives illustrate that PAC services are used often as opportunities for interrogation and punishment 
rather than to provide quality treatment and information to women about their future options to prevent unwanted pregnancy and unsafe abortion. 42

During 2004 and 2005, there was unprecedented public debate on the topic of abortion and equally unprecedented political will to address inhumane post-abortion care. Two landmark studies played an important role in fomenting consciousness about the abuses taking place in public sector health services when women sought care for complications of unsafe abortion and in demanding and defining action so that such violations would not continue. A Human Rights Watch (HRW) study conducted in Argentina in 2005 documented inadequate and inhumane treatment occurring in public sector health services, including the performance of uterine evacuation (UE) procedures without adequate pain control and outright denial of services. ${ }^{43}$ For example, one social worker from the Santa Fe province stated: "A woman [we work with] went to the hospital in a very bad state from an abortion, and she was infected and hemorrhaging. A doctor started to examine her, and when he realized [she had had an abortion] he threw his instruments on the floor. He said: 'This is an abortion, you go ahead and die!'"44 This same study also reported that women often avoid seeking PAC services for fear of being reported to the police because many physicians believe that they must denounce women seeking care for abortion complications. The HRW study culminated in a series of recommendations to the Argentine government, international donor agencies, and the Federation of Argentine Societies of Gynecology and Obstetrics, calling for decisive actions to improve contraceptive and PAC services throughout the country. ${ }^{45}$

Research conducted in Rosario, in the Santa Fe province, exposed mistreatment of women by hospital staff, lack of information and communication with women about their condition and medical interventions, and interrogation and punishment by hospital personnel when they suspected that women had induced their abortions. ${ }^{46}$ The findings were presented in a series of forums and reports that compelled government and health care services to take action to reform the PAC service provision. Steele and Chiarotti state that initial denial by some health professionals that there was a serious problem was replaced by critical self-assessment within the 
provincial government, hospitals, and medical and nursing schools, with a subsequent commitment to reform hospital practices and the medical school curriculum. Women participants also gained an understanding of their right to appropriate and humane health care.

\section{PAC Services in Public Hospitals in Tucumán: Using EvalAPA to Assess Quality and Respect for Human Rights}

This article has discussed the dire need for improving PAC services in Argentina. If sustainable changes are to be made, health service providers, administrators, and policymakers need to see the problems clearly in order to develop feasible solutions.

We now present the use of a rights-based, healthservice-based tool to evaluate the quality of PAC services and offer guidance on specific areas that need to be improved. We posit that EvalAPA, a user-friendly, simple tool, can be used by health service workers to identify areas that are working well and services that need to be strengthened. The results can then be used by health sector staff to improve services so that women receive the quality care they deserve and to which they have a right.

Data from Tucumán public hospitals show that, from 1993-2000, abortion complications accounted for $38 \%$ of maternal mortality. The age-adjusted mean maternal mortality ratio (MMR) varied significantly by the age of the woman; higher maternal mortality was seen among adult women rather than teens (Figure 2). However, the contribution of unsafe abortion to maternal mortality was higher among teens than among adult women: $48 \%$ compared with $34 \%$, respectively. 47

Given this context and the direct experience of two of the co-authors in Tucumán health facilities, an evaluation of PAC services in the province's three hospitals (of a total of 323 health centers and 34 hospitals) that offer obstetric care was undertaken. For confidentiality reasons, facilities' name are protected, and they are identified only as A, B, and C. We evaluated tertiary- and secondary-level hospitals that care for women with gynecological emergencies, including complications of unsafe abortion, in Tucumán, between February and May 2003. 


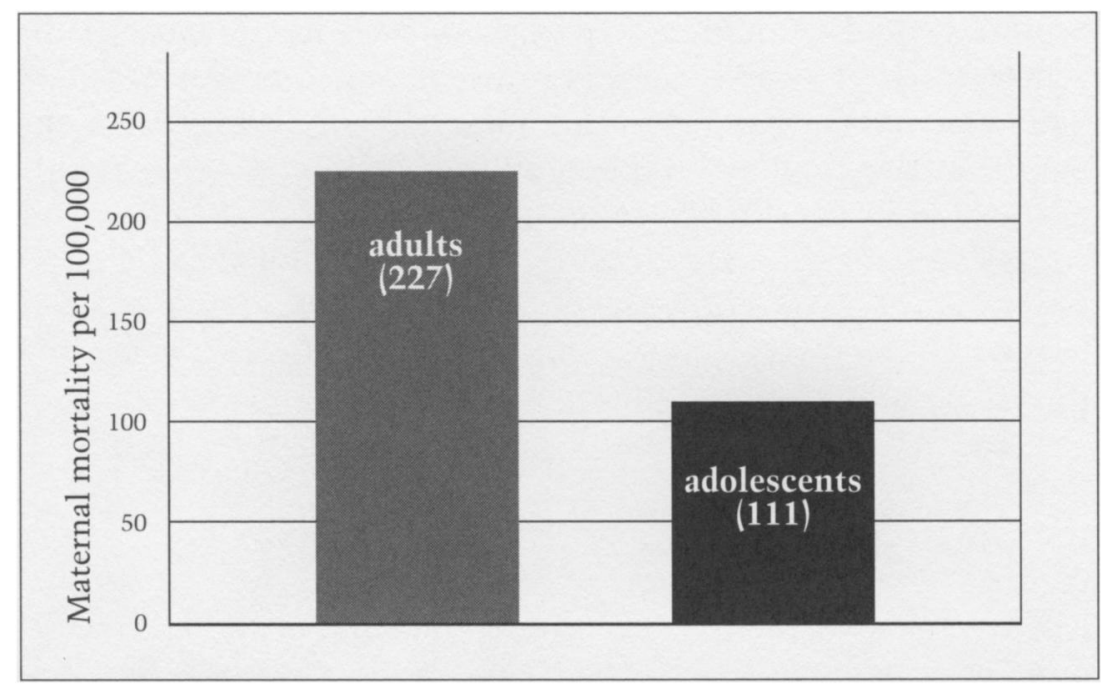

Figure 2. Maternal Mortality in Adults and Teens in Maternity Hospital, Tucumán, 1993-2000. Source: C. Steele and S. Chiarotti, "With Everything Exposed: Cruelty in Post-Abortion Care in Rosario, Argentina"

Reproductive Health Matters 12/24/Supplement (2004): pp. 39-46.

\section{Methodology}

EvalAPA ${ }^{48}$ was developed by Ipas and tested extensively in Peru, Nicaragua, El Salvador, and other Ipas programmatic countries. ${ }^{49-53}$ Its structure is based on the PAC general frame-

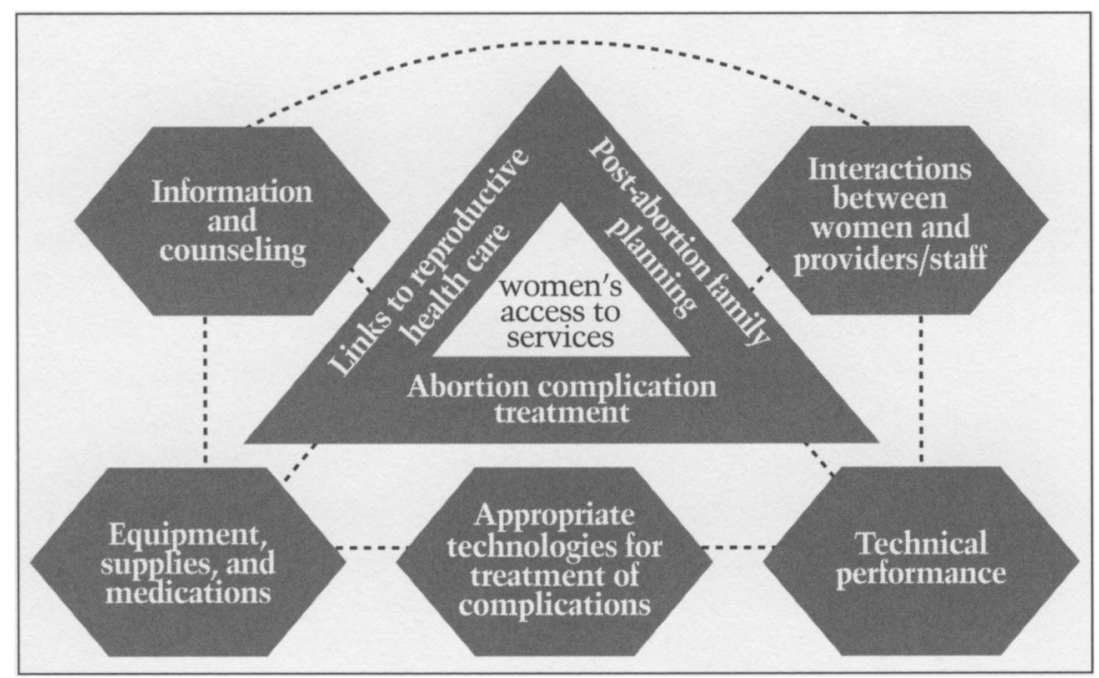

Figure 3. PAC Framework for Quality of Care. Source: A. Leonard and I. Winkler, "Marco Conceptual de Calidad de Atención para el Tratamiento del Aborto," Adelantos en el Tratamiento del Aborto 11 (1991): pp. 1-4.

Health and Human Rights 
work for quality of care (Figure 3), which has been used in service-related work and research throughout the world. ${ }^{54}$ The framework highlights the basic elements needed to ensure that the care that women receive is comprehensive, humane, and respectful of a range of rights, including health and access to scientific advances. EvalAPA is a tool that helps to pinpoint where and how the quality of care framework is not being put into practice and, thus, which areas need to be improved so that human rights violations are not being incurred.

EvalAPA assesses quality of care during three stages of care: 1) the pre-uterine evacuation procedure period, 2) during the UE procedure, and 3) post-UE. The pre-procedure stage is defined as the time when a woman comes to the facility looking for medical attention up to the time of the UE procedure; "during" refers to the procedure itself; and post-UE refers to the period after the procedure up to hospital discharge. The tool uses 108 questions or guides for observations, divided among three general modules. Fifty-four questions refer to direct observation of services, 37 require review of clinical records, 43 are questions posed directly to health care providers (obstetricians-gynecologists [ob-gyns], anesthesiologists, nurses, psychologists, and supervisors), and 50 questions are asked of patients. In many cases, the same questions require different sources of information to verify responses, consequently allowing the previous numbers to add up to more than 108. The wording of each module was tested and validated in Spanish during development of the final EvalAPA tool. .55

In addition to using EvalAPA, we conducted a total of four focus groups, two with women treated for abortion complications ( $n=6$ per group) and two with staff members and residents in obstetrics and gynecology ( $\mathrm{n}=10$ per group) (see Table 1 for topics explored). Women were invited to participate before their discharge from the hospital, at which time they provided verbal informed consent. They were recruited during the time of the study by verbal invitation; no incentives were provided, only a friendly space to talk. Saturation criteria were used for analyzing responses in each hospital. Twenty in-depth interviews with patients and 20 with health care providers - 10 ob-gyn residents, 5 staff ob-gyns, 3 psychologists and 2 midwives - were also conducted to confirm the information collected with EvalAPA. 


\begin{tabular}{|c|c|}
\hline Topics for Women Patients & Topics for Health Care Providers \\
\hline $\begin{array}{l}\text { Payment for services; women's } \\
\text { ability to pay }\end{array}$ & $\begin{array}{l}\text { Practices and Abilities } \\
\text { Following biosecurity norms } \\
\text { Technical competency to provide } \\
\text { clinical care to women with } \\
\text { incomplete abortion } \\
\text { Identifying patients' needs related to } \\
\text { comfort } \\
\text { Perspective on whether women } \\
\text { seeking care for abortion complica- } \\
\text { tions should be reported to the police }\end{array}$ \\
\hline $\begin{array}{l}\text { Pain control received before, } \\
\text { during, and after UE procedure }\end{array}$ & $\begin{array}{l}\text { Hospital Norms and Procedures } \\
\text { Selection of type of pain control (gen- } \\
\text { eral, regional, or local anesthesia) ac- } \\
\text { cording to patient's clinical condition } \\
\text { Selection of technology for UE } \\
\text { (MVA, SC, other) } \\
\text { Mechanisms to refer patients to other } \\
\text { reproductive health services, as needed }\end{array}$ \\
\hline $\begin{array}{l}\text { Health status evaluation conducted } \\
\text { by hospital staff before, during, and } \\
\text { after UE procedure }\end{array}$ & $\begin{array}{l}\text { Evaluation of care provided } \\
\text { Strengths and weaknesses } \\
\text { Changes that need to be made } \\
\text { Perceptions of patients/evaluation } \\
\text { of care received }\end{array}$ \\
\hline $\begin{array}{l}\text { Health Staff Rapport with Women } \\
\text { Introduction of self before initiating care } \\
\text { Clarity of language used and } \\
\text { information presented } \\
\text { Asking about women's concerns and } \\
\text { satisfying women's need for information } \\
\text { Ensuring women's comfort }\end{array}$ & \\
\hline $\begin{array}{l}\text { Information Provided to Women } \\
\text { Different options for performing the } \\
\text { UE procedure } \\
\text { Signs for possible complications or } \\
\text { problems post-UE procedure } \\
\text { Contraceptive methods } \\
\text { Temporary need to abstain from sex to } \\
\text { avoid immediate pregnancy } \\
\text { Other reproductive health needs, in- } \\
\text { cluding prevention of sexually trans- } \\
\text { mitted infections (STIs) }\end{array}$ & $\begin{array}{l}\text { * The process: manual vacuum aspira- } \\
\text { tion (MVA); sharp curettage (SC) }\end{array}$ \\
\hline
\end{tabular}

Table 1. Focus Groups' Topics of Discussion. 


\section{Description of Study Hospitals}

Table 2 outlines the basic characteristics of the three hospitals included in this study. All are located in or near the capital city of San Miguel de Tucumán, have an ob-gyn residency program, serve low- to medium-income women, and provide services free of charge. These include obstetric, neonatal, and gynecological emergency care; prenatal care; infant care; family planning; and gynecological cancer care as core maternal and child health care.

There is considerable variation among the hospitals in terms of size, caseload, and mortality due to unsafe abortion. Hospital A has the highest number of births and post-abortion care patients in all of Argentina. Hospital B is a general hospital with a gynecology service. Hospital $\mathrm{C}$ is a regional hospital with an obstetric and gynecologic service. 56 During 2002, the Ministry of Health initiated a program whereby women with abortion complications would be referred from Hospital A to Hospital B, located nearby and with a lower caseload of patients. Given their different institutional profiles, the number of providers trained in resolving obstetric emergencies in general and abortion-related complications in partic-

\begin{tabular}{|c|c|c|c|}
\hline & Hospital A & Hospital B & Hospital C \\
\hline Hospital Type & $\begin{array}{c}\text { Maternity } \\
\text { Teaching Hospital }\end{array}$ & $\begin{array}{c}\text { General } \\
\text { Teaching Hospital }\end{array}$ & $\begin{array}{c}\text { Regional } \\
\text { Teaching Hospital }\end{array}$ \\
\hline $\begin{array}{l}\text { Procedure Used for } \\
\text { Uterine Evacuation }\end{array}$ & Sharp Curettage & Sharp Curettage & Sharp Curettage \\
\hline \# Deliveries/Yr. & 11,892 & 0 & 2,500 \\
\hline \# of PAC Patients/Yr. & 2,363 & 236 & 383 \\
\hline $\begin{array}{l}\text { \# of Deaths Due } \\
\text { to Abortion Compli- } \\
\text { cations in } 2002\end{array}$ & 4 & 2 & 1 \\
\hline $\begin{array}{l}\text { Abortion Case } \\
\text { Fatality Ratio (CFR), } \\
2002^{\star}\end{array}$ & 1.7 per 1,000 & 8.5 per 1,000 & 2.6 per 1,000 \\
\hline \multicolumn{4}{|c|}{ This is calculated using the following formula } \\
\hline \multicolumn{4}{|c|}{ CFR: $\frac{\text { number of abortion deaths }}{\text { total number of abortions }} \times 1,000$} \\
\hline
\end{tabular}

Table 2. Characteristics of Each Study Hospital, 2002. 
ular vary from hospital to hospital. Hospital A shows a downward trend while Hospital $\mathrm{C}$ maintains a constant number of cases attended per month. Hospital B, however, experiences a significant increase in the number of patients, $76 \%$ of which occurs during 2002.

\section{Results: EvalAPA, Focus Groups, and Interviews}

The percentages of "quality" calculated by EvalAPA are based on the responses to 12 open-ended questions about the facility and 96 close-ended questions about different aspects of quality of care..$^{57}$ The results were expressed in quartiles of positive answers, using a color code during evaluation for rapid visual assessment.

- $\quad 0-24 \%=$ unacceptable quality, alert, urgent need to be addressed

- $25-49 \%$ = need to be improved using a controlled intervention

- $\quad 50-75 \%=$ acceptable level of quality; only needs adjustment

- $\quad 75-100 \%$ = optimal quality of care

Tables 3, 4, and 5 present the "grades" of quality of care, according to the EvalAPA tool, for each stage during a woman's stay in the hospital (pre-, during- and post-UE procedure).

\begin{tabular}{|l|c|c|c|}
\hline $\begin{array}{l}\text { Pre-Procedure } \\
\text { Quality }\end{array}$ & Hospital A & Hospital B & Hospital C \\
\hline $\begin{array}{l}\text { Technical } \\
\text { Competency }\end{array}$ & $43 \%$ & $14 \%$ & $14 \%$ \\
\hline $\begin{array}{l}\text { Appropriate } \\
\text { Technologies }\end{array}$ & $50 \%$ & $50 \%$ & $60 \%$ \\
\hline $\begin{array}{l}\text { Equipment and } \\
\text { Supplies }\end{array}$ & $100 \%{ }^{\star}$ & $0 \%$ & $20 \%$ \\
\hline $\begin{array}{l}\text { Counseling } \\
\text { Patient-Provider } \\
\text { Interaction }\end{array}$ & $0 \%$ & $0 \%$ & $33 \%$ \\
\hline PAC Services Access & $40 \%$ & $33 \%$ & $0 \%$ \\
\hline
\end{tabular}

* Optimal quality

Table 3. Quality of Care: Pre-UE Procedure, Three Hospitals, Tucumán. 


\begin{tabular}{|l|c|c|c|}
\hline Intra-Procedure Quality & Hospital A & Hospital B & Hospital C \\
\hline Technical Competency & $12 \%$ & $0 \%$ & $10 \%$ \\
\hline $\begin{array}{l}\text { Appropriate } \\
\text { Technologies }\end{array}$ & $33 \%$ & $0 \%$ & $33 \%$ \\
\hline Equipment and Supplies & $67 \%^{\star \star}$ & $17 \%$ & $17 \%$ \\
\hline Counseling & $50 \%{ }^{\star \star}$ & $0 \%$ & $0 \%$ \\
\hline $\begin{array}{l}\text { Patient-Provider } \\
\text { Interaction }\end{array}$ & $40 \%$ & $20 \%$ & $20 \%$ \\
\hline PAC Services Access & $67 \% \star \star$ & $33 \%$ & $0 \%$ \\
\hline
\end{tabular}

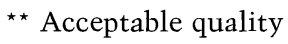

Table 4. Quality of Care: During-UE Procedure PAC, Three Hospitals, Tucumán.

During all three stages of care, Hospital A consistently scored the best, while Hospital B demonstrated the worst quality of care. All three hospitals, however, needed to improve technical competency and patient-provider interactions substantially.

Table 6 presents a summary of quality of care measures for three main elements of PAC services: treatment of abortion complications, post-abortion contraceptive services,

\begin{tabular}{|c|c|c|c|}
\hline Post-Procedure Quality & Hospital A & Hospital B & Hospital C \\
\hline Technical Competency & $80 \%$ * & $0 \%$ & $17 \%$ \\
\hline $\begin{array}{l}\text { Appropriate } \\
\text { technologies }\end{array}$ & $50 \%$ ** & $0 \%$ & $50 \%$ ** \\
\hline Equipment and Supplies & $80 \%$ * & $0 \%$ & $20 \%$ \\
\hline Counseling & $100 \%$ * & $20 \%$ & 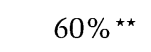 \\
\hline $\begin{array}{l}\text { Patient-Provider } \\
\text { Interaction }\end{array}$ & $20 \%$ & $38 \%$ & $25 \%$ \\
\hline PAC Services Access & $14 \%$ & 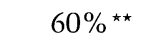 & $12 \%$ \\
\hline
\end{tabular}

*Optimal quality $\quad{ }^{\star \star}$ Acceptable quality

Table 5. Quality of Care: Post-UE Procedure PAC, Three Hospitals, Tucumán. 
and links to other reproductive-health services. Only Hospital A scored at an acceptable level and only on the technical element of treatment of complications. Overall, the delivery of each element of care at all three hospitals needs to be improved. Without such changes, women's basic needs during their care are not being met, thereby compromising their full access to multiple rights. When women leave the hospital without having experienced quality care for their complications or links to other reproductive health services as needed, health problems can ensue. Likewise, if they have not received basic information about options to help prevent unwanted pregnancies, as well as the methods to do so, women may resort again to unsafe abortion, putting both their health and lives at risk.

The time that women spend waiting for care is also a significant factor in the quality of care received. Women can suffer negative health consequences when they are moved from area to area and their care is delayed. In addition, this increases the cost of care unnecessarily, without improving the quality of care. To measure this variable, EvalAPA has a standardized format for implementing a time-motion study with a randomly selected sub-sample of patients on different days of the week and during different times of the day. These patients were followed by a trained medical resident throughout their process of care. The resident counted the number of stages through which women passed as well as the length of time of each stage, which was determined with a chronometer. As with similar studies conducted throughout the world, only women who did not suffer from

\begin{tabular}{|l|c|c|c|}
\hline $\begin{array}{l}\text { Quality PAC } \\
\text { Elements }\end{array}$ & Hospital A & Hospital B & Hospital C \\
\hline $\begin{array}{l}\text { Quality in Treatment } \\
\text { of Complications }\end{array}$ & $50 \%$ ** & $14 \%$ & $18 \%$ \\
\hline $\begin{array}{l}\text { Quality in } \\
\begin{array}{l}\text { Contraception } \\
\text { Post-Procedure }\end{array}\end{array}$ & $33 \%$ & $9 \%$ & $27 \%$ \\
\hline $\begin{array}{l}\text { Linking with Other } \\
\text { Services }\end{array}$ & $40 \%{ }^{*}$ & $25 \%$ & $25 \%$ \\
\hline
\end{tabular}

Table 6. PAC Elements Analysis in Public Hospitals in Tucumán. 


\begin{tabular}{|l|c|c|c|}
\hline $\begin{array}{l}\text { Stages in the } \\
\text { Institution }\end{array}$ & Hospital A & Hospital B & Hospital C \\
\hline Number of Stages & 6 & 6 & 8 \\
\hline Time in Days & 1.26 days & 2.05 days & 3.18 days \\
\hline
\end{tabular}

Table 7. Mean Duration of PAC in Tucumán's Public Hospitals.

complications other than those from an incomplete abortion were included in the sub-sample to control for situations that might result in extensively long hospital stays and would unfairly skew the results. 58 Table 7 illustrates that most women needed to pass through six to eight stages during their care and needed to stay in the hospital between 1.2 and 3.1 days. Options for reorganizing services on an ambulatory care basis using manual vacuum aspiration (MVA) rather than sharp curettage (SC) have been tested successfully throughout Latin America. ${ }^{59}$ Such interventions could drastically reduce the time spent by women in the hospital, as well as the total cost of PAC services.

Given these results, it is worth highlighting that the abortion case fatality ratio (CFR) (see Table 2) is not related necessarily to the number of women attended, but to the quality of services delivered in each institution. Hospital B attends the fewest number of women with abortion complications of the three hospitals, but also has the least number and quality of trained providers, resulting in the highest fatality ratio. In fact, its ratio of 8.5 deaths per 1,000 abortions is double that defined as acceptable by the World Health Organization for developing countries. ${ }^{60}$ This indicator highlights the important link between quality of care, abortion-related mortality, and morbidity that can be reduced with better training and equipping in PAC services.

Focus group and in-depth interviews illustrate similar conclusions about the quality of care offered in these three hospitals and add a layer of depth and complexity to the ways in which quality of care and human rights interact to leave women either with a sense of empowerment or with a sense of vulnerability and violation. Unfortunately, in most cases, women felt the latter, as illustrated through the following quotes: 
I wanted my partner to accompany me, but they would not even let him get near me. They took him out [of the room] to ask him what I had done to myself, if he knew what I had done to 'lose' the pregnancy. (30-year-old woman with several children)

The woman in the reception area of the hospital told me when she saw me, 'Ah, one more who does these things and then they come here so we can solve their problem.' I had to wait a long time until she even let the doctors know I was there. I had a fever and a lot of pain. I just cried, sitting there, and waiting. What else could I do? (16-year-old girl with incomplete abortion and infection)

Every time that I told the doctor that I was in pain, [to] please let me have anesthesia, he would tell me to relax, that we were finishing [the procedure], that there was just a little more to go. He also said that I should have thought a little more before putting the pill in my vagina ... and that I should thank him for not reporting me to the police. (Woman with five children, attended in the emergency area)

I was lying there with my legs open when I awoke, and there were a lot of people in this little room. I think they were all students. I was really embarrassed; I just asked them to cover me up. I was so embarrassed. (Young woman attended in the emergency area)

At the same time, several women expressed their gratitude that hospital staff had resolved their "problem" and noted that the quality of care they received was acceptable.

Health care providers offered their own perspectives on the quality of care, often highlighting the multiple barriers and challenges they face in providing good care, even when they have a strong desire to do so. Others expressed frankly their opposition to abortion and their negative attitudes toward women who abort, thereby justifying actions that can rise to the level of human rights violations. Some mentioned their belief that these women ought to be reported to the police:

What would I change? I think I'd put all of the women to sleep [with anesthesia]. It's very difficult to be sure that you've finished the procedure well when they're moving and screaming, and more than anything when you have the family knocking on the door all of the time when they hear her. We don't have much privacy in the service. (40-year-old female gynecologist) 
We don't have many sheets for the beds, and we only change them when they're wet with blood. Sometimes various women share the same sheets before we are able to wash them. But they are better off here than in their homes. At least here, we have mattresses and sheets. The worst is when we have to put two women in the same bed, but sometimes it is necessary. There are so many of them, and we have to keep them here for at least two days to be sure that they don't have an infection. (Chief of gynecology services)

You know what I'd change? The Head [of services]. He doesn't let us use anesthesia for the procedures [done with sharp curettage]. I'd change him. (32-year old male gynecologist)

I don't give them anesthesia, even if the chief of services requests it. I have many years of experience as an anesthesiologist, and I'll tell you that if you don't make these abortionists [the women] suffer, they don't learn. And on top of this, I have to think about whether it hurts them or not. (56-year-old male anesthesiologist)

We've all done it at some time, in desperation . . . verbal aggression, procedures without anesthesia, threats, punishment. I can't believe it, I feel like a monster, but one has to be here [in the hospital] and to see the state in which the women arrive. (50-year-old male gynecologist)

The head of the gynecology surgery ward in one of the hospitals noted that, since no written norms for PAC existed, all women treated for complications were reported to the police by the physician on-call so that the "police intervention would serve as a form of security for the health care team."

\section{Discussion}

The findings from this research are consistent with previous studies on PAC in public hospitals in Argentina. Human Rights Watch (HRW) recommended in June 2005 that the Ministry of Health publish and distribute a guide on how to deliver quality post-abortion care and require all health care providers, public as well as private, to provide such care. HRW also recommended that the Ministry ensure that all women know and understand that they will be provided with humane post-abortion care at public and private 
health centers and hospitals. In 2006, the Ministry of Health of Argentina launched a new guide for improving PAC quality, which includes switching from the use of sharp curettage to manual vacuum aspiration, when appropriate, and the provision of post-abortion contraceptive counseling and services. ${ }^{6}$

\section{Actions Taken in Tucumán Post-Evaluation}

In partnership with the local director of the Maternal and Child Health Department of the Public Health System and the School of Medicine at the National University of Tucumán, Ipas sponsored a Training of Trainers (TOT) session in April 2005. They invited 30 health care providers and 10 heads of the maternal and child health departments in local ministries of health from five northwestern provinces. An initial sensitization meeting was held with decisionmakers exploring the benefits of the woman-centered PAC model and reviewing Ipas' program, policy, and research experiences in Latin America during the past 10 years. ${ }^{62}$ All three hospitals from Tucumán were included in the training activities, as were staff from 11 hospitals from border provinces in the northwest region of Argentina. With support from Ipas Bolivia and a supportive government official from that country, a fertile and open space for discussion and learning developed. Post-workshop evaluations demonstrate that improvements were made in both knowledge and attitudes among ob-gyns who committed themselves to introducing the PAC model in their own hospitals. ${ }^{63}$ Participants received training manuals, pelvic models, and MVA instruments, which were donated by Ipas. Additionally, the School of Medicine's last year of intern practicum included preservice training in PAC services, using Ipas educational materials. Simultaneously, at the national level, the Argentine government drafted the National Norms for the Improvement of PAC Quality and scheduled it for a March 2006 launch, but at the time of this publication this had not yet taken place. Conclusions from other PAC evaluation projects were shared in different forums throughout the country, which have motivated actions on the part of Health Department officials. 


\section{Conclusion}

In Argentina, activists from various sectors are creating new opportunities in public health policies, including the Law and National Program for Sexual Health and Responsible Procreation, provincial laws and programs, and, in general, increased visibility of reproductive and sexual rights. ${ }^{64}$ These changes present important opportunities to use research and evaluation results from innovative methodologies, incite profound changes in health care service delivery, and move toward the implementation of models that enable patients to exercise their human rights and health care providers to facilitate that process.

EvalAPA is a useful tool for evaluating the quality of PAC services and encouraging discussion in health services about ways in which improvements can be made. It is not, however, without its limitations. Results garnered should be used to detect areas of strength and weakness, but are not specific enough to provide absolute guidance on solutions. As such, processing the results with a variety of staff members and discussing implications are key to maintaining areas that are strong and developing strategies to improve problem areas. Another limitation is that EvalAPA measures only three of the five elements of PAC. Future versions should include the elements of community partnership and general counseling.

Improving the quality of PAC services and working to create informed demand by the public are basic human rights issues. As noted in ICPD PoA paragraph 8.25, women should have access to quality services for the management of complications arising from unsafe abortion. Health care providers have the right to access the most cost-effective, safe, and evidence-based technologies for patient care. Women have the rights to health, dignity, privacy, information, and life, among others, which can be exercised when quality PAC services are available and accessible to them. Using evidence-based practices in a woman-centered PAC model not only would reduce maternal mortality and morbidity but would create spaces in which women's rights would be respected. 


\section{References}

1. World Health Organization, ICPD+5: Gains for Women Despite Opposition. Available at http://www.crlp.org/pdf/pub_bp_ICPD+5.pdf.

2. World Health Organization, The Prevention and Management of Unsafe Abortion: Report of a Technical Working Group, WHO/MSM/92.5 (Geneva: WHO, 1992). Available at http://www.who.int/reproductivehealth/ publications/MSM_97_16/MSM_97_16_chapter2.en.html.

3. E. Ahman and I. Shah, Unsafe Abortion: Global and Regional Estimates of the Incidence of Unsafe Abortion and Associated Mortality in 2000, Fourth Edition (Geneva: WHO, 2004): pp. 8-16.

4. Ibid.: pp. 13-17

5. Alan Guttmacher Institute, Aborto Clandestino: Una Realidad Latinoamericana (New York: AGI, 1994): pp. 14-29; International Planned Parenthood Federation, Death and Denial: Unsafe Abortion and Poverty (London: IPPF, 2006): pp. 4-26. Available at hhtp://www.ippfwhy. org/publications/download/monographs/Death_Denial_Sp.pdf.

6. S. Ramos, M. Romero, R. Mercer, S. Weller, C. del Río Fortuna, M. Molinas, A. Karolinski, F. Althabe et al., "Mortalidad Materna en la Argentina: Diagnóstico para la Reorientación de Políticas y Programas de Salud," Informe Final (Buenos Aires, Argentina: Center for the Study of the State and Society [CEDES], Ministerio de salud/ CONAPRIS, CLAP [OPS/OMS], May 2004). Available at http://www.cedes.org/english/informacion/ci/publicaciones/index.html.

7. World Health Organization, Planificación Familiar Postaborto Guía Práctica para Administradores de Programas. Available at http:// www.who.int/reproductivehealth/publications/es/post_abortion_family_ planning.

8. Human Rights Watch, Decisions Denied: Women's Access to Contraceptives and Abortion in Argentina 17/1 (B) (June 2005): pp. 57-63. Available at http://hrw.org/reports/2005/argentina0605/index.htm.

9. C. Steele and S. Chiarotti, "With Everything Exposed: Cruelty in PostAbortion Care in Rosario, Argentina" Reproductive Health Matters 12/ 24/Supplement (2004): pp. 39-46.

10. Post-Abortion Care Consortium, Basic Elements. Available at http://www.pac-consortium.org.

11. J. Herrick, K. Turner, T. McInerney, and L. Castleman, WomanCentered Post-Abortion Care: Reference Manual (Chapel Hill, NC: Ipas, 2004): pp. 3-182.

12. H. L. McNaughton, K. Padilla, E. Hernández, P. de Hernández, and P. Ramİrez, Entre La Espada y la Pared: el Secreto Profesional y la Atención Post Aborto (Managua, Nicaragua: Ipas Centroamérica, 2004): pp. 13-33. 13. Universal Declaration of Human Rights (UDHR), G.A. Res. $217 \mathrm{~A}$ (III), UN GAOR, Res. 71, UN Doc. A/810 (1948), Article 25(1); International Covenant on Economic, Social and Cultural Rights (ICESCR), G.A. Res. 2200 (XXI), UN GAOR, 21 st Sess., Supp. No. 16, at 49, UN Doc. A/6316 (1966), Article 12; Convention on the Rights of the Child (CRC), G.A. Res. 44/25, UN GAOR, 44th Sess., Supp. No. 49, at 166, UN Doc. A/44/25 (1989), Article 24; Convention on the Elimination of All Forms of Discrimination against Women (CEDAW), G.A. Res. 34/180, UN GAOR, 
34th Sess., Supp. No. 46, at 193, UN Doc. A/34/46 (1979), Article 12; and the right to nondiscrimination as reflected in the International Convention on the Elimination of All Forms of Racial Discrimination (ICERD), G.A. res. 2106 (XX), Annex, 20 U.N. GAOR Supp. No. 14, at 47, UN Doc. A/6014 (1966), Article 5(e)(iv).

14. For an in-depth discussion about the link between PAC and human rights, see R. J. Cook, B. M. Dickens, and M. F. Fathalla, Reproductive Rights and Human Rights: Integrating Medicine, Ethics, and Law (Oxford: Clarendon Press, 2003): pp. 211-96.

15. B. R. Johnson, S. Ndhlovu, S. L. Farr, T. Chipato "Reducing Unplanned Pregnancy and Abortion in Zimbabwe Through Post-Abortion Contraception," Studies in Family Planning 33(2) (2002): pp. 195-202.

16. A. Leonard, A. Ladipo, "Post-Abortion Family Planning: Factors in Individual Choice of Contraceptive Methods," Advances in Abortion Care 4(2) (1994): pp. 1-4.

17. D. Billings and J. Benson, "Post-Abortion Care in Latin America: A Summary of a Decade of Operations Research," Health Policy and Planning 20/3 (2005): pp. 158-66.

18. Código Penal Argentino, Libro Segundo, De los delitos, "Título IDelitos contra las Personas," Articles 85-86. Available at http://www.portaldeabogados.com.ar/codigos/codpenal03.htm.

19. N. P. Rodríguez, "Se Hacen 800.000 Abortos por Año. Lo Aseguró el Ministro de Salud," La Nación (December 17, 2005). Available at http: //www.lanacion.com.ar/informaciongeneral/nota.asp?nota_id=765597.

20. M. Gogna, Las Reformas en el Sector Salud en la Argentina y ChileOportunidades y Obstáculos para la Promoción de la Salud Sexual y Reproductiva, lera Edición (Buenos Aires: CEDES, 2004): p. 302. Available at http://www.cedes.org/informacion/ci/novedades_ci/pub_recientes.html. 21. R. Giustiniani, "Hablar de Aborto," Página/12, Edición del Viernes (November 15, 2002). Available at http://www.pagina12. com.ar/diario/suplementos/las12/13-425-2002-11-15.html.

22. E. Gómez, La Salud Y Las Mujeres En América Latina Y El Caribe Viejos Problemas Y Nuevos Enfoques-Serie Mujer y Desarrollo 17, Programa Regional Mujer, Salud y Desarrollo, División de Salud y Desarrollo Humano, de la Organización Panamericana de la Salud (OPS), a la sexta Conferencia Regional sobre la Integración de la Mujer en el Desarrollo Económico y Social de América Latina y el Caribe (Mar del Plata, Argentina: September 25-29, 1994).

23. Ministerio de Salud y Ambiente de la Nación, Dirección Nacional de Salud Materno-infantil, Nacional Norm: Guía para el Mejoramiento de la Atención Post-aborto - Manual de Atención (Republica Argentina: 2005). Available at http://www.msal.gov.ar/htm/Site/salud_sexual/downloads/ Pdf\%20post-aborto\%20final.zip.

24. S. K. Henshaw, U. Singh, and H. Taylor, "The Incidence of Abortion Worldwide: Implementing ICPD in Latin America, Ensuring Women's Access to Safe Abortion Care," International Family Planning Perspectives 25/Supplement (1999): pp. 30-8.

25. Instituto Nacional de Estadística y Censos de la Republica Argentina (Indec), "Situación y Evolución Social," Publicación 30 (1998). Available 
at http://www.indec.mecon.ar/anuario/index_infonac.htm.

26. United Nations Population Fund, Monitoring ICPD Goals - Selected Indicators (2005). Available at http://www.unfpa.org/swp/2005/images/ e_indicator1.pdf and http://www.unfpa.org/swp/2005/images/e_indicator 2.pdf.

27. Instituto Nacional de Estadística y Censos de la Republica Argentina (Indec 2005), Segundo semestre 2005: Incidencia de la Pobreza e Indigencia en el Total de los 28 Aglomerados Urbanos y por Región Estadística. Available at http://www.indec.mecon.gov.ar/.

28. M. Montenegro, "Pobres al por Mayor en el Primer Año de Gestión," Página/12 (January 31, 2001). Available at http://www.pagina12.com.ar/ 2001/01-01/01-01-31/pag03.htm.

29. M. Romero, D. Maceira, S. Weller, R. Mercer, L. Aizemberg, and G. Dinardi (eds), "Rights and Reforms Initiative," Initiative for Sexual and Reproductive Rights in Health Sector Reforms: Latin America (Buenos Aires: Center for the Study of the State and Society [CEDES], 2000). Available at http://www.cedes.org.

30. M. Bianco, "The Regional Action Plan to Reduce Maternal Mortality in the Americas Places Argentina Among Countries with High Maternal Mortality," "Fecundidad Salud y Pobreza en America Latina: El Caso Argentino," Fundación para el Estudio e Investigación de la Mujer (1996). Available at http://www.metabase.net/docs/las-dignas/00382.html.

31. T. Durand and M. Gutiérrez, "Cuerpo de Mujer: Consideraciones Sobre los Derechos Sociales, Sexuales y Reproductivos en la Argentina," in M. Bianco, C. Zurutuza, T. Durand, and M. A. Gutiérrez (eds), Mujeres Sanas, Ciudadanas Libres (o el Poder de Decidir), 27 (1998).

32. Mortalidad Materna en la Argentina (see note 6).

33. Human Rights Watch, see note 8.

34. D. Rocco, "Mortalidad Materna Por Aborto en la Argentina de 1980 al 2000," Obstetricia y Ginecologia Latino Americana 60/4 (2002): pp. $184-9$.

35. M. Gogna (see note 20): pp. 99-113.

36. M. Bianco "Qué Servicios y para Quiénes?" Foro por los Derechos Reproductivos et al. (eds), Mujeres Sanas, Ciudadanas Libres (o el Poder para Decidir) 82 (1998): pp. 1-13. Available at http://www.cels.org.ar/ Site_cels/publicaciones/informes_pdf.

37. Ley Nacional \#25.673, Creación del Programa Nacional de Salud Sexual y Procreación Responsable. Available at http://www.portaldeabogados.com.ar/codigos/25673.htm and http://www.aapf.com.ar/legislacion.htm.

38. Instituto Nacional de Estadística y Censos de la Republica Argentina (Indec), Republica Argentina. Available at http://www.indec.mecon.ar/.

39. D. Grech, "Argentina and Birth Control: Clash over Contraceptives Plays Out in Impoverished Province," Miami Herald (October 7, 2003).

40. R. Gomez Ponce de Leon, N. Ciocolani, M. Mazzamuto, E. Hurtado, and T. Ardissono de Medina, "Mortalidad Materna en la Adolescente, un Indicador de la Política Sanitaria: Revista de la Sociedad de Ginecología y Obstetricia de Tucumán," SOGOTUC Científica 1/1 (2001): pp. 28-30.

41. M. Carbajal, "Childbirth in Hell: One Report Shows the Violence 
Suffered by Women in Tucumán, in the Biggest Maternity Hospital of the Country," Página/12 (December 21, 2003). Available at http://www. pagina12.com.ar/diario/sociedad/3-29564-2003-12-21.html.

42. N. Zamberlin, Propuesta para Mejorar la Calidad de la Atención en las Complicaciones de Abortos (Argentina: CEDES, 2005). Available at http://www.msal.gov.ar/htm/site/pdf/Informe \%20final\%20Nina $\% 20 \mathrm{Za}$ mberlin.pdf. (Accessed February 2006.)

43. Human Rights Watch, see note 8 .

44. Ibid.: p. 57.

45. Ibid.: p. 9.

46. Steele and Chiarotti, see note 9 .

47. Gomez Ponce de Leon et al., see note 40.

48. Available through the Ipas research and training units, at compac@ ipas.org.

49. V. Huapaya, J. Benson., H. Verastegui, and J. Parra, "Results of a National Post-Abortion Care Service Survey in Peru" (Paper presented at the annual meeting of the American Public Health Association, Philadelphia: October 2002).

50. J. Benson, Sustainability of Post-Abortion Care in Peru, Doctoral dissertation (University of North Carolina at Chapel Hill, School of Public Health, Department of Maternal and Child Health: 2003).

51. J. Benson and V. Huapaya, "Sustainability of Post-Abortion Care in Peru: Report of Rapid Assessment Visits to Four Hospitals," Final Report to the Frontiers Project (Chapel Hill, NC: Ipas, 2002).

52. J. Benson, V. Huapaya, M. Abernathy, and T. King, "Improving Quality and Lowering Costs in an Integrated Post-Abortion Care Model in Peru," Final Report to the INOPAL III Project (Carrboro, NC: Ipas, 1998).

53. D. Billings (ed), Investigaciones en Accion: Atención Postaborto en Cuatro Países de América Latina (Mexico City: Ipas, 2005). Available at http://www.ipas.org.

54. A. Leonard and J. Winkler, "Marco Conceptual de Calidad de Atención para el Tratamiento del Aborto," Adelantos en el Tratamiento del Aborto 11 (1991): pp. 1-4.

55. V. Huapaya, J. Parra, H. Verástegui, J. Benson, EvalAPA: Sistema de Información del Análisis Rápido de la Calidad de los Servicios de Atención Postaborto Versión 2.0 (Chapel Hill, NC: Ipas, 2002).

56. R. Gomez Ponce de León and K. Barrionuevo, Evaluation of Quality of Post-Abortion Care in Tucumán, Argentina - Centro de Estudios Materno Infantiles de Tucumán (CESMIT) \& Ipas (Chapel Hill, NC: Ipas, 2004).

57. T. Baird, V. Chambers, and C. Hord, "Como Implementar la Atencion Post Aborto," Recursos, Técnicos para la Atención Post Aborto (Chapel Hill, NC: Ipas, 19981.

58. M. B. Weinger, O. W. Herndon, M. H. Zornow, M. P. Paulus, D. M. Gaba, and L. T. Dallen, "An Objective Methodology for Task Analysis and Workload Assessment in Anesthesia Providers," Anesthesiology 1/80 (1994): pp. 77-92.

59. D. Billings and J. Benson, "Post-Abortion Care in Latin America: A Summary of a Decade of Operations Research," Health Policy and 
Planning 20/3 (2005): pp. 158-66.

60. E. Ahman and I. Shah, Unsafe Abortion: Global and Regional Estimates of Incidence of Unsafe Abortion and Associated Mortality, Fourth Edition (Geneva: World Health Organization, 2004).

61. Ministerio de Salud de la Republica Argentina,Resolución 989/2005 - Apruébese la Guía para el Mejoramiento de la Atención Post Aborto e incorpórase la misma al Programa Nacional de Garantía de Calidad de la Atención Médica. Available at http://www.feim.org.ar/resolucion989. doc.

62. Billings and Benson, see note 59 .

63. K. Barrionuevo, D. Lipchak, R. Pérez, Zambrana, Primer Taller Nacional De Capacitación En Ameu, "Evidencia Cientifica en Ginecologia y la Practica Diaria: Atencion De Las Hemorragias Del Primer Trimestre Del Embarazo," San Miguel De Tucumán (Argentina), Centro de Estudios Materno-infantiles de Tucumán (CESMIT), Hospital Alvarez (Buenos Aires: Ipas, June 20-22, 2004).

64. M. Romero and D. Maceira (eds), "Rights and Reforms Initiative," Initiative for Sexual and Reproductive Rights in Health Sector Reforms: Latin America (Argentina: CEDES, 2000). Available at http://www.wits.ac.za/whp/ rightsandreforms/docs/CommunityparticipationLAFINAL.pdf. 